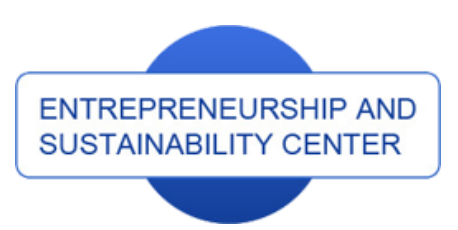

Publisher

http://jssidoi.org/esc/home

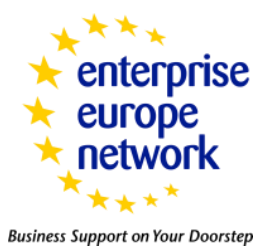

CASPA

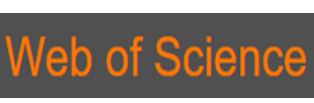

1) Clarivate

\title{
TOWARDS FOOD SECURITY AND SUSTAINABLE DEVELOPMENT THROUGH ENHANCING EFFICIENCY OF GRAIN INDUSTRY*
}

\author{
Kanat Tireuov $^{1}$, Salima Mizanbekova ${ }^{2}$, Bakhyt Kalykova $^{3}$, Gulmira Nurmanbekova $^{4}$ \\ 1,2,3,4 Kazakh National Agrarian University, Abay Avenue 8, Almaty, The Republic of Kazakhstan \\ E-mails: nurmanbekova_g@mail.ru
}

Received 27 February 2018; accepted 20 August 2018; published 30 September 2018

\begin{abstract}
The new situation of Kazakhstan's participation in the world grain market, which requires scientific generalization, is connected with the transformation of the country's trade turnover from interregional to interstate. In this connection, it is objectively necessary to scientifically and methodically substantiate the system of inter-branch cooperation between enterprises for the production and sale of grain and grain processing products in order to ensure stable provision of demand for them in the regions of the country with minimum costs and export it to foreign markets. The problem of increasing the efficiency of the use of grain requires a comprehensive reduction in its consumption across all consumption channels: on seeds, when processed into flour and cereals, for forage purposes. The paramount importance of effective inter-industry cooperation between grain sub-sector organizations is determined by the leading role of grain in the economy of the agro-industrial complex, food security, and the formation of state, interstate and interregional economic ties of the country. In the current situation, the stable functioning of the grain market should be carried out on the basis of a combination of market mechanisms with state regulation tools and targeted support of its subjects.
\end{abstract}

Keywords: food security; sustainable development; interindustry interaction; grain products' sub-complex; grain market; state regulation; economic relations; innovations; grain storage; methods; methodology; tools; mechanism; The Republic of Kazakhstan

Reference to this paper should be made as follows: Tireuov, K.; Mizanbekova, S.; Kalykova, B.; Nurmanbekova, G. 2018. Towards food security and sustainable development through enhancing efficiency of grain industry, Enterpreneurship and Sustainability Issues 6(1): 446455. http://doi.org/10.9770/jesi.2018.6.1(27)

JEL Classifications: O1, Q1

Additional disciplines (besides field of economics reflected in JEL classifications): biochemistry; ecology and environment

\footnotetext{
"The research is supported by a project" Inter-sectoral economic interaction of enterprises (organizations) of the grain products sub-complex in the conditions of the contemporary agro-industrial policy" financed by Ministry of Education and Science of The Republic of Kazakhstan
} 
The International Journal

ENTREPRENEURSHIP AND SUSTAINABILITY ISSUES

ISSN 2345-0282 (online) http://jssidoi.org/jesi/

2018 Volume 6 Number 1 (September)

http://doi.org/10.9770/jesi.2018.6.1(27)

\section{Introduction}

Sustainable development of countries embraces array of facets among food security plays one of the most important roles (e.g.; Bilan et al., 2017; Svetlanská et al. 2017; Skrypnyk et al., 2018; Tvaronavičienė, 2018).

For Kazakhstan, the development of inter-sectoral economic interaction of the grain product sub-complex has a special role in connection with the strategic importance of grain and grain products as basic food products, raw materials for processing industry and livestock, a resource for state reserves and the main commodity in demand on world markets. In the development of the grain market, interbranch economic relations on the sale of grain and grain products. A new, requiring scientific generalization, the situation of Kazakhstan's participation in the world grain market is connected with the formation of sovereign states and the transformation of trade turnover between them from interregional to interstate. The existing form of interbranch relations of agricultural producers, organizations of storage, processing, trade, intermediary structures and infrastructure links, does not contribute to the achievement of a synergetic effect, ensuring the sustainability of management and increasing the competitiveness of products, weakly orientates the production functional process for implementing the strategy of import substitution in the agrifood sector. It is also necessary to meet the requirements of Kazakhstan's scientific recommendations on the formation of a system of state regulation of the interstate and interregional grain market (Tireuov, 2016a, 2016b). The structure of the grain product sub-complex is determined by the production of cereals in agriculture, the purchase of grain and it's processing in industries (flour, cereals, food and feed). In modern conditions, systemic problems that were manifested in the early 1990s and remain in the new century remain unresolved. The most important of these are the low level of profitability of agricultural producers, a large number of intermediaries, the unsatisfactory condition of the material and technical base of infrastructure enterprises, the underutilization of production capacities, the stagnation of domestic machinery for the food industry and agriculture.

\section{Methods of research}

Grain products subcomplex. Zernoproduktny subcomplex of the republic represents a vertically integrated structure, its organizational and production relations are characterized by insufficient balance and uneven pace of development of complex-forming industries. Especially low rates of development have developed in its processing and infrastructure spheres. This involves large losses of grain and grain products. Annually at the joints of the industries engaged in the production of grain, and carrying out its storage and processing, up to $20 \%$ of the harvested crop is lost. The main causes of losses are incomplete use of available raw materials, territorial disconnection of technologically interconnected industries. Hence, there are unreasonable inter-regional and interstate transportation of raw materials and products, associated with high transport costs and losses. The existing economic mechanism of the subcomplex does not meet the needs of the developing market economy and does not ensure coordination, coherence and necessary docking of all links in the production of final products, which ultimately leads to destabilization of the consumer market of food products. Forming a significant part of the fund of grain resources, the republic covers its needs for finished products at the expense of its own production by $90-95 \%$. In the structure of the grain produced in the republic, the greatest proportion is wheat, mainly of strong and hard varieties, for cultivation of which favorable soil-climatic conditions have developed in Kazakhstan. However, unreasonable location of production and purchase of wheat in the regions, without taking into account zonal features led to the placement of crops and the formation of forage crops in the republic according to the residual principle. This caused a disproportion between the funds of food and feed grain. At a level of supply with food grains exceeding the norm, the need for fodder is satisfied only by $80 \%$. The experience of countries operating on the basis of developed commodity production shows that the mechanism of the open 


\section{The International Journal \\ ENTREPRENEURSHIP AND SUSTAINABILITY ISSUES}

ISSN 2345-0282 (online) http://jssidoi.org/jesi/

2018 Volume 6 Number 1 (September)

http://doi.org/10.9770/jesi.2018.6.1(27)

market can not by itself fully coordinate the activities of industries that are interrelated in the process of production of ready-to-use final products (Tireuov, 2016a, 2016b).

As stabilizing measures aimed at weakening the spontaneity of the market, direct long-term ties between isolated and economically independent commodity producers are implemented, which are realized on the basis of orders of the society and mutual obligations for the supply of specialized products, balanced in time, range and quality. The target orientation of the subcomplex in the process of harmonization of production, technological and market programs calls for deepening specialization in the production of a certain group of goods from grain taking into account demand (structure and volume of needs) and market conditions. Integration of industries for the production of final products from grain resources within the framework of the subcomplex, their functioning as an integrated production and economic system will contribute to the improvement of production technology, its organization, the regulation of economic relations of partners, the distribution of resources between them in the priority development of technological links that inhibit production growth final products. The branch (grain) market, in turn, developing the mechanism of adaptation of production to changing demand, stimulating competition among enterprises, will purposefully regulate the activities of all the links included in the subcomplex, which will allow to establish optimal inter-industry proportions and to form on this basis an effective structure providing maximum efficiency with minimal total costs and ensure export of grain and grain products (Altukhov,2015).

\section{The discussion of the results}

As is well known, they are used for the production of flour, cereals and mixed fodder, for feeding cattle and poultry in unprocessed form, for seeds, for technical processing. At the flour-grinding and cereal enterprises of the country, the yield of flour and croup of high varieties is much lower than in developed countries. Most of the feed grain in the country is fed to livestock and poultry in its pure form, despite the high efficiency of its use in the processed form in the composition of mixed fodders. The problem of improving the efficiency of the use of grain requires a reduction in its consumption across all consumption channels: on seeds, in processing for flour and cereals, for forage purposes. Its solution is adversely affected by the lack of the formation of an effectively functioning market for grain and grain products. Issues of economic relations between the grain sub-sector: the provision of mutual services by the grain elevator industry and grain producers, as well as the complex of agricultural relations with the flour-grinding and feed milling industry, the terms of export supplies in the economic literature are not fully covered. They are determined by the formation of the agrarian market as part of the world interstate and regional markets; transformation of forms of ownership; the new economic role of the state in the conditions of its transition from administrative to economic measures of influence on production and distribution of products of branches (Kaliev, Akimbekova, 2015). However, in the conditions of a market economy, the establishment of economic relations is hampered by the surviving monopoly of industries, the underdevelopment of the labor and capital market, which impedes changes in interindustry proportions, the disorder of the financial and credit system, and the violation of established territorial ties. In this regard, specific state measures are needed to regulate inter-industry economic relations, and complex scientific research should be carried out for their justification (Zakashevsky, 2017).

The production of grain is the most priority sector in the development of agriculture in Kazakhstan. It occupies one of the leading places in the agro-industrial complex and in the whole in the economy of Kazakhstan. In Kazakhstan, more than $80 \%$ of all sown areas are accounted for by grain crops. The main grain production is concentrated in Northern Kazakhstan.Favorable natural conditions in this region make it possible to obtain high and stable grain yields, first of all, high-gluten food wheat, which is in high demand on world markets as an improver for the baking properties of flour. The aggregate share of the northern regions of Kazakhstan (Akmola, Kostanay, North Kazakhstan) in the total grain production is $75 \%$. According to average data, over the past five 


\section{The International Journal}

ENTREPRENEURSHIP AND SUSTAINABILITY ISSUES

ISSN 2345-0282 (online) http://jssidoi.org/jesi/

2018 Volume 6 Number 1 (September)

http://doi.org/10.9770/jesi.2018.6.1(27)

years, the annual carryover stocks of grain are about 14 million tons. According to the forecasts of the Food and Agriculture Organization of the United Nations (FAO), the growth of global wheat production until 2020, expected at $11 \%$. Kazakhstan will increase grain production by $40 \%$ mainly due to the increase in yields. The growth of global production of fodder cereals will go at an accelerating rate in relation to food crops, by about 20\% (Moldashev, 2016:7).

As of May 2018, the reserves of grain and leguminous crops in Kazakhstan amounted to 9.462 million tons, including 1.652 million tons in peasant (farm) households, of which wheat 7,975 million tons, of which 6,088 million tons tons - food, 1.345 million tons - for seeds and 542 thousand tons - forage. As analysis of the role of the state in the grain market showed, state intervention in this sphere is to some extent present in all countries, but not everywhere it is done with the same efficiency. Let us dwell in more detail on the foreign experience of state regulation of agricultural production. Despite the principles of the free market, the need for state intervention in the agricultural production process is due to the following reasons:

1. In the conditions of technical progress and intensification of agricultural production, on the one hand, there is a significant need for capital, on the other hand, there is a relatively low return on capital, which is explained by the specifics of the industry: the spatial dispersion of the economy, the seasonality of work, the variety of forms of activity, duration of the use of equipment during the year. This indicates that agricultural production is a more capital-intensive industry in comparison with other branches of the national economy. At the same time, due to objective reasons and nature of production, the contribution of the industry to the gross national product per worker, the profitability of production and labor productivity in agriculture are lower than in other industries.

2. In agriculture, the difference in terms of costs and production is reached in crop production - 10-12 months, and in livestock - 2 years or more. In such conditions, agriculture cannot compete with other branches of the national economy.

3. Agriculture is a special branch that is connected with all spheres of economic activity and depends on natural natural processes. This, in turn, requires the preservation of the terrain and the natural environment, landscape, ecology, securing the population in historical habitats, maintaining the traditional way of life. 4. The efficiency of agricultural production and the collection of grain depend largely on the natural and climatic conditions, the timing of sowing and harvesting.

5. Agricultural production is relatively inelastic depending on prices, especially if price fluctuations are shortterm. Demand for food is poorly elastic, depending on price fluctuations. The population is relatively stable in consuming basic foodstuffs, and only with a sharp increase in the prices of individual products and a decrease in real incomes it goes to a forced reduction in consumption. There are differences in the level of elasticity of demand, depending on prices and incomes: the greatest changes occur in meat and meat products, the smallest in bread, potatoes, and milk. There is a time lag between price changes and the corresponding reaction of agricultural production in the fund-producing industries, as well as in processing, agroservice, 6. There is a problem of land ownership. Land is not only the main means of production in agriculture, it is also a territorial factor of statehood, national self-determination, a spatial basis for the functioning of the entire national economy, a pantry of minerals, a special object of social relations. The refusal of the state from power over land can engender corruption in the land market, which is fraught not only with the Food, but also with the national security of the country.

7. In the agricultural industry, the effect of intensification factors is slowed down: fertilizers, land reclamation, land reclamation, innovative technologies yield returns at a certain time interval. 8. Close ties in the grain market lead to a high correlation between the efficiency of the entire agricultural cycle and the need to change production. A whole complex of state measures of an economic and administrative nature was created to maintain market equilibrium and stabilize agricultural production, which cannot be solved by traditional market mechanisms.

The revealed features of the functioning of the agrarian sphere of the economy show that this sphere is objectively 
The International Journal

ENTREPRENEURSHIP AND SUSTAINABILITY ISSUES

ISSN 2345-0282 (online) http://jssidoi.org/jesi/

2018 Volume 6 Number 1 (September)

http://doi.org/10.9770/jesi.2018.6.1(27)

unable to compete with other branches of the national economy, this requires a different attitude to agriculture on the part of the power structures. To equalize the social conditions and the quality of life of urban and rural populations, the governments of developed countries provide financial, organizational and political support to the industry, which is regarded as an obligatory and unconditional element of public policy (Dnishev, 2015: 532 p.).

As the study showed, state regulation of agriculture abroad is a complex mechanism that includes instruments for influencing farmers' incomes, the structure of agricultural production, the agrarian market, the social structure of the village, inter-industry and inter-farm relations with the aim of creating stable economic, legal and social conditions for development agriculture, meeting the needs of the population in quality food at socially acceptable prices, protecting the environment fluidized bed (Mizanbekova S., 2017:45). Currently, the main content of the agrarian policy of most economically developed countries is state support for the agricultural sector through various subsidies, subsidies and benefits. The measures of direct state subsidies include the support of farmers' incomes, which consists of: direct state compensatory payments; payments for damage from natural disasters; payments for damage associated with the reorganization of production (payments for reducing the acreage, forced slaughter of cattle, etc.).

Measures of indirect state regulation of the agroindustrial complex include: 1. Price intervention on the food market by supporting domestic prices for agricultural products, setting quotas and tariffs, setting taxes on the export and import of food.

2. Compensation of the costs of agricultural producers for the acquisition of means of production by granting subsidies for the purchase of fertilizers, pesticides and forages, payment of interest on loans received, payments for property insurance.

3. Assistance to the development of the market, providing for the allocation of public funds for the development and implementation of market-based programs, subsidies for the storage of goods and transport operations for the transport of products.

4. Assistance to the development of industrial infrastructure, which involves the allocation of public funds for long-term activities that ensure the growth of production efficiency - subsidies for the construction of production facilities, irrigation projects, land reclamation, and to promote the establishment of farmers' associations.

In countries with developed market economies, there is an active state intervention in the formation and regulation of prices, which provides: the establishment of the upper and lower limits of price fluctuations and the indicative or conditional price that the state seeks to support; buying or selling non-perishable goods for the purpose of commodity intervention and maintaining the desired price level. One of the most important indicators of state regulation of agriculture in developed countries is the level of budgetary support for farm prices for manufactured products. This indicator is characterized by the ratio of all price and non-price budgetary subsidies for the production and sale (including export) of a particular type of agricultural products to its farm price. The study confirmed that the national subsidies are provided within the framework of a pan-European subsidy policy in strict accordance with its principles. Any other assistance (price interventions (surcharges to prices), regulation of production volumes, high compensation for export products), which creates the most favorable conditions within a country, is prohibited. At the same time, national governments can participate in financing and carrying out measures to improve the quality of products, ensure veterinary supervision, introduce scientific and technological progress, protect the environment, stimulate production in so-called problem areas, ensure minimum income for smallholders. Budget support can be provided by both EU member states and their autonomous entities (autonomous regions of Italy, departments and districts of France, counties in Germany) or federal states (German lands) that have their budgets (income from taxes). However, it was determined that the absolute amount of subsidies for investments should not exceed a given amount. Despite the fact that the national agrarian policy in the EU countries is a continuation of the Uniform Agricultural Policy, there are significant differences in the directions and methods of financing agriculture. For example, in support of production and markets, in addition to the EU system, Denmark spends a third of its agricultural budget, Britain and Ireland, respectively, 15 and $20 \%$. 


\section{The International Journal}

ENTREPRENEURSHIP AND SUSTAINABILITY ISSUES

ISSN 2345-0282 (online) http://jssidoi.org/jesi/

2018 Volume 6 Number 1 (September)

http://doi.org/10.9770/jesi.2018.6.1(27)

Almost all countries spend half of their national agricultural budgets on structural policy (this includes modernization and consolidation of farms, improvement of land and other agricultural resources, improvement of farmers' operations, reduction of production costs and development of unfavorable areas). At the same time, there are significant differences in these areas of expenditure. For example, the UK directs almost a third of its agricultural budget to the modernization programs, while the Netherlands and Luxembourg - less than $10 \%$. In general, in the EU countries, an average of $10 \%$ of agrarian budgets are channeled to support start-up farmers, including 25\% in France, in Britain and Ireland this item is insignificant. On the budget programs "Research and development" on the average for the EU is sent about $10 \%$, and in the Netherlands - almost $30 \%$ of the budget (Mizanbekova, Bogomolova, 2015; Mizanbekova, Bogomolova, 2017).

The US also subsidizes agriculture. Budgetary spending on agriculture depends on the economic situation - during the crisis years their importance increases sharply, in more stable periods the level of state subsidies is significantly reduced. Budget funds are allocated for the financing of the following programs: agricultural research; organization of marketing and information about markets and prices; crediting; conservation and seizure of land; support of prices, purchase, compensation payments; support of farming supply and marketing cooperatives, market orders; subsidizing food; export subsidies; international food aid. It should be noted that in the structure of budget expenditures allocated to agriculture, the main are two areas: income stabilization programs (accounting for about $60 \%$ of budget expenditures under the item "Agriculture"); program of agricultural research and science services. The largest share of aid (about $70 \%$ of budget funds) is received by relatively large farms that ensure high production efficiency, and in fact, one-third of American farms are covered by budgetary financing. As the research has shown, in all major grain-producing countries the grain economy is subsidized. The EU countries, the USA, Canada, Japan, India are investing heavily in improving grain production technologies. This allows to save $52.7 \%$ of potential crop losses in the EU countries, the United States - 44\%. The foregoing allows us to conclude that state regulation of the agro-industrial sector of the economy through comprehensive support of agricultural producers is a priority direction of the agrarian policy of most developed countries. At the same time, various economic levers are used (payments from the budget, compensation of production costs, price support, subsidies for improving the production structure, development and implementation of various programs), the action of which allows creating favorable conditions for ensuring sustainable functioning of the agro-industrial complex and forming an effective social and production infrastructure in the countryside.

Since the production of grain is at the heart of the technological chain "agriculture - grain-processing enterprises grain processing", it must be subject to state regulation. The support of agricultural producers, taking into account the rational elements of the foreign experience of state regulation, taking into account the national peculiarities and the economic situation, is especially important when Kazakhstan joins and functions in the conditions of the WTO and tightens competition for the domestic grain and bakery market (Nurmanbekova, 2015: p. 44). At the same time, state regulation in the technological chain under consideration should be multi-purpose, maintaining stability, efficiency, democracy and fairness of the functioning of its participants, regardless of the form of ownership and sphere of activity. Summarizing the opinions of domestic and foreign scientists, it seems fair to strengthen the organizing and controlling intervention of the state only taking into account market selfregulation. State regulation of market conditions within the globalization of the economy, taking into account the specified principles, will create conditions for the sustainable development of the civilized domestic grain market and the mobilization of Kazakhstan's export potential (Nurmanbekova, 2015:p. 44). Prospects for inter-industry cooperation are associated with the possibility of further improving technology. The potential of intersectoral interaction should be considered proceeding from the fact that any specific technological process should be considered as part of a more complex process and as an aggregate of less complex technological processes, each of which is capable of both creating unique competitive advantages and leveling the advantages of other processes. Along with the specialization and differentiation of industries, processes of cooperation and integration 
The International Journal

ENTREPRENEURSHIP AND SUSTAINABILITY ISSUES

ISSN 2345-0282 (online) http://jssidoi.org/jesi/

2018 Volume 6 Number 1 (September)

http://doi.org/10.9770/jesi.2018.6.1(27)

are taking place, which leads to the formation of stable production links between industries and the creation of inter-branch complexes. Almost every science-intensive branch can be considered as an interbranch complex, which is an integration structure that is characterized by the interaction of various industries and their elements, different stages of production and distribution of products.

Innovative activity is a strategic direction for the development of the grain product subcomplex of Kazakhstan. The ways of transfer to the innovation-investment model of development can be considered in the following directions: innovations of technical and technological nature, innovations in the biological factor. Without an accelerated transition to an innovative development path in the context of the globalization of economic relations aggravating competition in the world agro-food market, the tasks of agro-industrial policy cannot be resolved.Innovative activity refers to the type of activity associated with the transformation of an idea into a new or improved product, a new or improved technological process used in practice. Pilot projects are being implemented in a number of regions. In Kazakhstan (Akmola region) a new granary of the agrofirm "Aktyk" with a capacity of up to 30 thousand tons was launched. The construction of the granary was financed from the funds of the National Fund. Thanks to the new elevator, the agrofirm will be able to store and store large quantities of grain, bring them to the conditioning state without loss of consumer properties for a long period of time. The granary is intended for receiving grain from motor transport, cleaning and storage in silos. The bakery does not only accept, dry and ship wheat, but also oilseeds, the price of oilseeds is much higher than for wheat. About 1,000 hectares of flax are sown with the possibility of receiving products at a new grain receiving point. This granary is just one of many erected elevators in Kazakhstan with the financing of KazAgroFinance JSC. In total, since 2009, JSC "KazAgroFinance" approved 18 projects of grain storage facilities with a capacity of 275,000 tons for a total of KZT10, 850 million. Since the beginning of this year, two grain storage facilities with a capacity of 24,000 tons have been put into operation. Five grain storage facilities with a total storage capacity of 143,000 tons are planned to be commissioned by the end of the year. A new elevator with a design capacity of 120,000 tons is operating in Petropavlovsk (Kazakhstan) -Export »An elevator per hour can take more than 600 tons of grain. The total capacity of the granary is 120 thousand tons. The elevator uses the latest technologies with the use of American-made equipment that allows to provide the whole range of services: reception, processing, drying, storage and shipment of grain and oilseeds.

New innovative energy-saving technologies are used, which reduce energy consumption by 3-4 times. With the launch of the elevator, 96 new jobs were opened. In total in the North Kazakhstan region of Kazakhstan there are more than 50 licensed grain receiving enterprises, the total capacity of which is about 3.5 million tons. In Kazakhstan (Kostanai oblast) the company Agro-Bio-Auliekol LLP plans to build a plant for deep processing of wheat worth about KZT1.5 bn., an additional land plot with a railway dead-end and a land plot for filtration fields are provided. Agro Bio Auliekol LLP has already launched an innovative project to create a whole biotechnological complex for deep processing of wheat and wheat straw with a volume of more than 10,000 tons per year, producing modified starch, dry gluten, glucose-fructose syrup and mixed fodder with increasing protein content . In the situation of falling grain prices, due to the limited domestic and export markets, the way out for the grain-growing regions is the development of deep grain processing. This will also reduce the dependence of grain growing regions on fluctuations in world wheat prices. Grain-producing regions of the country produce only three types of basic grain-processing products - grain, flour and bran, while the introduction of biotechnological processes will produce $100 \%$ of wheat processing and produce about 19 types of highly liquid products. This will raise the economy of the grain-growing regions to a new level, with the opening of new jobs, science-intensive industries. The development of new directions in the processing of wheat leads to conservation and stimulation in the expansion of sown areas, which will not only preserve but also increase the employment of the rural population. There will be tangible results: if a ton of wheat is sold at 50,000 tenge, when processing the same ton of wheat, up to 618 thousand tenge. The plans to open an experimental shop for the production of bio-feed. The use of full-fledged developments in the field of biotechnology will make it possible to obtain high-nutritional 


\section{The International Journal}

ENTREPRENEURSHIP AND SUSTAINABILITY ISSUES

ISSN 2345-0282 (online) http://jssidoi.org/jesi/ 2018 Volume 6 Number 1 (September) http://doi.org/10.9770/jesi.2018.6.1(27)

compound feeds containing protein (protein) over 20\%, raw fat $8 \%$, crude fiber $25 \%$, deficient amino acid "lysine" 7\% and other macro- and microelements from straw. The cost of such bio-feeds will not exceed the existing prices in the market of feed mixes and mixed fodders, and, unlike the approximate "premixes", will be much lower. This type of feed production is environmentally friendly, cost-effective and has a social background (in view of the high protein content, the growth in live livestock is accelerating without increasing costs, which will positively affect the economic component of the population). The Belarusian National Biotechnology Corporation (BNBK) is embarking on a large-scale investment project "Organization of a high-tech agroindustrial full cycle production for 2016-2032. The project includes the construction and commissioning of a plant for the production of lysine, plants for the production of threonine and tryptophan, factories for the production of mixed fodders, a complex of grain storage facilities, an auto plant, an administrative complex, a research laboratory, an electrical substation, a steam turbine plant, engineering and transport infrastructure. In Kazakhstan, the state program "Digital Kazakhstan", strategically important for the country, was adopted to prepare the economy for the fourth industrial revolution. In Aktyubinsk Oblast, a pilot project "Farmers Service Center" will be implemented with the use of digital technologies. New technologies are used for crops and harvesting. The main innovation is the transition to the electronic form of the issue of the grain receipt and the use of the information system by the grain market entities. This system will automate the accounting of grain receipts, their holders and operations with grain receipts. The first grain receipts from the Aktyubinsk region have been issued. The volume of output was 2 thousand tons of fodder grain, or about 80 million tenge at market value. Elevator in Astana issued its first grain receipts for a total volume of 20 thousand tons in the category of food grains. In the North-Kazakhstan region, grain receipts with a volume of 2.5 thousand tons were exported. An electronic map of granaries has also been put into operation, on it in the online mode the loaded and empty grain storage tanks are displayed, their maximum technical capacity. In addition, the system has implemented the opportunity to send an electronic receipt to the electronic trading platform of the State Register, on this site, the sale of objects of the second wave of privatization and all state assets are exhibited. In addition, participants in the grain market can take advantage of the option "delivery versus payment" when buying and selling grain receipts. This option is taken over from the securities market, and an electronic digital receipt in accordance with the adopted legislation is precisely a security. Thus, the grain receipt itself will be a payment instrument and a solid guaranteed currency. The Kazakhstan model of grain receipts was recognized by international experts as the best among the CIS countries and Eastern Europe using this financial instrument. Cereal receipts have long and successfully been used in the USA, Canada, Hungary, Bulgaria, and Russia. The introduction of grain receipts in Kazakhstan and, in particular, the creation of a Guarantee Fund for grain obligations, in addition to streamlining the system for the preservation and sale of grain, formed the basis for a significant attraction of financial resources to the grain economy. One of the directions is the creation of Kazakh-Russian joint centers for agricultural innovation in cooperation in the field of mutual investment, the operation of cross-border joint ventures, the construction of production chains, and the provision of high-quality transport and logistics infrastructure. Kazakhstan is completing the construction of the corridor Western Europe - Western China, going through Russia. Thanks to this, centers could be set up to expand food supplies using the resources of the Eurasian Development Bank. Of the Bank's 12 projects financed this year, 10 are in agriculture.

\section{Conclusions}

The state traditionally has a key role in the financial provision of the innovation process - the basis for modernizing the economy. It itself is a major, and in a number of countries and a major investor in new knowledge and technology. 21 The share of the state in domestic spending on research and development is $33 \%$ in the EU countries, the USA - 28, China - 25, Brazil - 50, India - 75\%. In addition, the state acts as a catalyst for innovative business activity, creating for it through various financial and fiscal mechanisms stimulating conditions that increase the efficiency of investments in the creation of high-tech products. There is a need to 
further improve the forms and instruments of state support, new financial mechanisms that make it possible to facilitate the commercialization of scientific knowledge, grant programs for conducting initial research on projects, and the expansion of the practice of setting up venture funds that invest in companies at the start-up phase. Unconditional priority remains the staffing of economic entities and the promotion of their products to the sales markets.

\section{References}

Altukhov, A.I.; Nechaev, V.I. 2015. Economic problems of innovative development of the grain products subcomplex of Russia. Monograph. Publishing house Nasirddinova VV, 477 p.

Bilan, Y.; Zos-Kior, M.; Nitsenko, V.; Sinelnikau, U.; Ilin, V. 2017. Social component in sustainable management of land resources, Journal of Security and Sustainability Issues 7(2): 287-300. https://doi.org/10.9770/jssi.2017.7.2(9)

Chow, K.V. 2018. Manufacturing Compounded Feeds in Developing CountriesFood and Agriculture Organization Rome, Italy.

Development of innovations and progressive technological structures in the economy of Kazakhstan in the conditions of industrial modernization: institutions, mechanisms and priorities / Ed. F. Dnishev, F. Alzhanova. - Vienna, Austria: Association for Advanced Studies and Higher Education "East-West", 2015. 532 p.

Epifanova, T.V.; Skvortsova, T.A.; Parshina, EA. 2017. Influence of clustering on innovation development of business structures in region's economy International Journal of Trade and Global Markets 10(2-3): 133-141.

Kaliev, G.A.; Akimbekova, G.U. 2015. Priority directions of development of processing of agricultural products in the Republic of Kazakhstan, Problems of the agro market 1: 5-10.

Kovács, J.K.; Zoltán, E.S. 2017. Rural Enterprise Hub Supporting Rural Entrepreneurship and Innovation-Case Studies from Hungary, European Countryside 9(3): 473-485.

Mizanbekova, S.K.; Bogomolova, I.P. 2015. Innovations as an instrument for sustainable development of the elevator industry in Kazakhstan and Russia. G. Economics, innovation, quality management. Voronezh State University of Engineering Technologies 4(13): 92-96.

Mizanbekova, S.K.; Bogomolova, I.P. 2017. Directions for the formation of balanced relations between the organizations of the grain product subcomplex The International Agricultural Journal 5: 45-49.

Moldashev, A.B. 2016. AIC of Kazakhstan: the problems of development and the search for their solution, Problems of the agro-market 3: $7-13$.

Nekrasov, R.; Anikinetal, A. 2018. Principles of rationing for compound feed concentrates in diets of highproducing cows, 2: 30-34 Nurmanbekova G.K. 2015. The competitiveness of grain as a factor in the effective development of grain production. J. Problems of the agro-market 15: 44-47.

Rankin, M.; Nogales, E.G.; Santacoloma, P.; Mhlanga, N.; Rizzo, C. 2016. Public-private partnerships for agribusiness development. Food and Agriculture Organization of The United Nations, Rome, 2016.

Rankin, M.; Nogales, E.G.; Santacoloma, P.; Mhlanga, N.; Rizzo, C.; Leitão, J.; Sarmento, E.D.E.; Aleluia, J. 2017. Public-Private Partnerships for Agricultural Transformation - Trends and Lessons from Developing Countries.Published: 6 December 2017. by Emerald (MCB UP) in The Emerald Handbook of Public-Private Partnerships in Developing and Emerging Economies, p. 191-219 https://doi.org/10.1108/978-1-78714-493-420171007 


\section{ENTREPRENEURSHIP AND SUSTAINABILITY ISSUES}

ISSN 2345-0282 (online) http://jssidoi.org/jesi/

2018 Volume 6 Number 1 (September)

http://doi.org/10.9770/jesi.2018.6.1(27)

Skrypnyk, A. V.; Tkachuk, V. A.; Andruschenko, V. M.; Bukin, E. 2018. Sustainable development facets: farmland and market demand estimation, Journal of Security and Sustainability Issues 7(3): 513-525. https://doi.org/10.9770/jssi.2018.7.3(11)

Svetlanská, T.; Turčeková, N.; Adamičková, I.; Skalský, R. 2017. Food security facets: case of Slovakia regions, Journal of Security and Sustainability Issues 7(2): 311-320. https://doi.org/10.9770/jssi.2017.7.2(11)

Tireuov K.M. 2016a. Agribusiness in a globalized economy. Monograph. Almaty, 2016, 229 p.

Tireuov KM 2016b. AIC of Kazakhstan: the organization of innovative activity. Monograph. Almaty, 2016, 162 p.

Tvaronavičienè, M. 2018. Toward efficient policy making: forecasts of vulnerability to external global threats, Journal of Security and Sustainability Issues 7(3): 591-600. https://doi.org/10.9770/jssi.2018.7.3(18)

Wu, J.; Zhuo, S.; Wu, Z. 2017. National innovation system, social entrepreneurship, and rural economic growth in China, Technological Forecasting and Social Change 121: 238-250.

Zakashevsky V., Charykova O., Kvasov A. 2017. Strategic development of the socio-economic development of the region's agro-industrial complex. J. APK: Economics, Management 12: 13 - 24

\section{Aknowledgements}

The research is supported by a project" Inter-sectoral economic interaction of enterprises (organizations) of the grain products sub-complex in the conditions of the contemporary agro-industrial policy" financed by Ministry of Education and Science of The Republic of Kazakhstan

Register for an ORCID ID:

https://orcid.org/register

Copyright (C) 2018 by author(s) and VsI Entrepreneurship and Sustainability Center This work is licensed under the Creative Commons Attribution International License (CC BY). http://creativecommons.org/licenses/by/4.0/

cC) (i) Open Access 